\title{
Determination or determinants? A debate based on the Theory on the Social Production of Health
}

\author{
Determinação ou Determinantes? Uma discussão com \\ base na Teoria da Produção Social da Saúde \\ ¿Determinación o determinantes? Una discusión con base \\ en la Teoría de la Producción Social de la Salud
}

Patrícia Rodrigues da Rochaํㅜ, Helena Maria Scherlowski Leal David ${ }^{2}$

${ }^{1} \mathrm{PhD}$, Graduate Program in Nursing. School of Nursing, State University of Rio de Janeiro, Rio of Janeiro, Brazil.

${ }^{2}$ Associate Professor, Graduate Program in Nursing. School of Nursing, State University of Rio de Janeiro, Rio of Janeiro, Brazil

\begin{abstract}
This article aims to discuss the concepts of Social Determination of Health and Social Determinants of Health, by establishing a comparison between each of their guiding perspectives and investigating their implications on the development of health policies and health actions. We propose a historical and conceptual reflection, highlighting the Theory on the Social Production of Health, followed by a debate on the concepts, with a comparative approach among them.
\end{abstract}

DESCRIPTORS

Social Determinants of Health; Epidemiology; Social Medicine; Public Health Nursing. 


\section{BACKGROUND}

Over time, a diversity of interpretive theories about the health/disease process has been developed, in order to search for causal inference in diseases. These theories express specific ways of thinking about the world and different philosophical projects, which can even be antagonistic towards each other ${ }^{(1)}$.

Since the implementation of the Organic Health Law in Brazil, Law n. 8,080/1990, Epidemiology has been explicitly denoted as a framework to support health actions within the Unified Health System (known by its Portuguese acronym, SUS). Conventionally, it is defined as a science that studies the distribution of diseases and their causes in populations. In the $20^{\text {th }}$ century, in addition to the expansion of epidemiological expertise, this matter was also recognized as a body of scientific knowledge, supporting practices related to public and community health ${ }^{(2)}$.

However, throughout decades, Epidemiology has not always had a collective perspective as its main object of study. It has also been used to reassure the legitimacy of clinical discourse, in the view of a biologistic design that has endured for a long time, leading the epistemological reflection to different paths, without connecting it to the social sciences ${ }^{(2)}$.

Epidemiology uses a predominantly inductive reasoning, namely, after the analysis of health occurrences in the population, it "(...) results in inferences that are applicable to other populations exposed to the same conditions" (2). For clinical discourse, in turn, the explanatory models for health/disease are restrictive. A healthy status means the absence of diseases, and health services are organized to provide preventive, curative and rehabilitative actions. "It does not consider the historicity of social facts, assuming the existence of universal standards of health/disease"(3).

Commonly, this concept of health - reduced to the mere absence of disease - proposes a purely biological perspective, which has received wide objection due to its lack of application in the analysis of social determination of health, as it focuses its perspective on the treatment and prevention of diseases/injuries and by this, thereby restricting the analysis of health-related issues ${ }^{(4)}$. One example is the progressively widespread application of the concept of risk as a tool to identify factors that increase the likelihood of diseases/injuries, with an increasing influence in decisions about the future of society. However, this desire to control is presented as a paradox, given the unpredictability of the health/disease phenomena ${ }^{(5)}$.

The social and historical nature of the health/disease process is empirically demonstrated by several studies. This is explained in the article "The health/disease as a social process" by Asa Cristina Laurell(6), which discusses the limitation of the biological conception of the disease and the influence of social and historical aspects in the disease process, through the findings of studies conducted in America and Europe. By clarifying this relationship, Laurell's study presented a concept related to the issue of determination ${ }^{(6)}$.
This article aims to discuss the concepts of Social Determination of Health and Social Determinants of Health $(\mathrm{SDH})$, establishing a comparison between their guiding perspectives and implications for health. We provide a brief historical and conceptual reflection, highlighting the Theory on Social Production of Health, followed by a discussion about concepts, with a concise comparative approach between them. Finally, we conclude by pointing out some implications related to health actions. This paper is based on studies conducted in the Research Group Settings of the Working World Occupational Health and Nursing, at the Nursing School of the State University of Rio de Janeiro.

\section{SOCIAL DETERMINATION OF HEALTH}

The concept of Social Determination of Health had a great importance in the development of social Epidemiology in Latin American and in the history of the Movement for Brazilian Health ${ }^{(7)}$. The origin of social medicine is related to the medical police in Germany, the urban medicine in France, and the occupational medicine in England. Through these three currents of thought, Foucault illustrates his thesis that "(...) with capitalism one did not pass from a collective medicine to a private medicine, but exactly the opposite "; that the capitalism, which develops at the end of the eighteenth century and the beginning of the nineteenth, "(...) socialized a first object, which was the body, as a function of the forces of production, of labor power" ${ }^{\prime(8)}$.

To Foucault ${ }^{(9)}$, "capitalism invested in the biological, the somatic, the corporeal, but in the working body, the worker's body, which would only be raised as an issue in the second half of the nineteenth century." It was only in the 1840s that conditions were created for the development of social medicine. "On the eve of a revolutionary movement that would spread across Europe, many physicians, philosophers and thinkers would recognize the social character of medicine and disease" ${ }^{\prime(9)}$.

From this moment, basic principles are integrated into the health discourse: 1) the health of the people is of interest to society, i.e., society is obliged to protect and ensure the health of its members; 2) social and economic conditions influence health and disease and these need to be studied scientifically; 3) the measures to be taken for the protection of health are both social and medical ${ }^{(9)}$.

"Undoubtedly, these ideas centralized in the medical corporation, as preached by Guérin, or marked by the relationships between men and their living conditions, as stated by Virchow, boosted the development of social medicine during the half of the nineteenth century"(9).

With the defeat of the 1848 Revolution, all these voices defending health as a political and social issue in Europe were suffocated. The ideology of the health movement and medicine as a social science were both transformed into a limited program for health reforms, leading to a total lack of importance given to social factors in health. In turn, the biomedical emphasis won overwhelmingly, as a result of the scientific revolution provided by Robert Koch's bacteriological discoveries ${ }^{(9)}$. 
In the late 1960 s, a controversy occurred regarding the nature of disease, due to the growing political and social crisis seen in capitalist countries that followed the economic crisis attached to it. The dominant paradigm of the disease, defined as an individual biological phenomena, began to be questioned, especially from the moment that the debate on the nature of the disease focused essentially in the social matter ${ }^{(6)}$.

The first Latin America general analyses that referred to the field of social medicine date back to the decades of the 1980s and 1990s. In Brazil, the social thinking pathway resulted in different approaches at different times. Such approaches were taken from the collective health origins, based on the so-called preventive project, widely discussed in the second half of the 1950s, which was associated with the criticism of the biomedical model and culminated in the creation of preventive and social medicine departments in medical schools, as well as disciplines that broadened the clinical perspective, such as Epidemiology, behavior sciences, and biostatistics. The concern of a biopsychosocial perspective for the individual finally took place ${ }^{(9)}$.

This understanding of the phenomena of health, disease and coping strategies relies on the social and scientific perspective based on the Marxist approach, which has been critical to the hegemonic science and purposeful when it comes to the need of strategies capable of developing new thoughts about health and new ways to organize and implement health practices and health actions ${ }^{(10)}$.

It starts from the recognition that, when it comes to the capital, the social relations of life production and reproduction are permeated and expressed by the contradictions inherent to the class projects in dispute; and that these contradictions, in turn, are expressed in uneven possibilities of living, experiencing illness and dying. Therefore, there is an epidemiological perspective that seeks to deepen the analysis beyond the indicators and the immediate phenomena, which enables the differentiation of not a single, but several epidemiological profiles in a given population, given that the social groups are concretely "exposed to different potentials of weaknesses and strengthening (...)"(10).

In the mid 1960s, the preventive project became a reality in many medical schools. The 1970 swere a milestone for the field of collective health in Brazil, which began its formal structure through the education of human resources in the improvement of social sciences in health and in the technological development and innovation by funding institutions. In 1974 the first social medicine graduate degree course was created in the city of Rio de Janeiro, and from the theoretical and academic perspective, the disclosure of several relevant works by authors such as Cecilia Donnangelo, Arouca, Luz, García, and many others ${ }^{(9)}$.

These studies are then disseminated by the Departments of Preventive and Social Medicine. In Arouca's study, Social Medicine investigates the dynamics of the health/disease process in populations, their relations with the health care structure, as well as theirs relations with the global social system, in order to transform these relation- ships and maximize the levels of health and well being of the populations ${ }^{(9)}$.

The development of social medicine in Brazil extends from 1974 to 1979 . However, it was only between 1980 and 1986, that this science was unfolded in proposals for an effective public policy through the dissemination of proposals to the healthcare system reform, expressed in important events, such as the VII and VIII National Health Conferences, which occurred in 1979 and 1986 respectively. The healthcare reform process then starts ${ }^{(9)}$.

A set of academic traditions studies the social determination of health/disease process: the Latin American social medicine, the collective health in Brazil and the Canadian health promotion movement. Although differently in relation to the scope and radicalism of their positions when it comes to the social order questioning, they all agree on the importance of social organization in the health aspects of a given territory and at a particular time. After all, health and disease not only depend on socioeconomic conditions, but also are influenced by others aspects ${ }^{(11)}$.

These approaches agreed that economic factors (income, employment and production organization) may interfere positively or negatively in the health of a population; that the living and working environments can generate more or less harmful effects on health; and that culture and values can also be interfering aspects by expanding or restricting the possibilities of people's health, differing in the sense that each one shares different thoughts on life, citizenship, health concept, and deals differently with gender, ethnic and economic differences ${ }^{(11)}$.

"Overall, the health/disease process is determined by the way the man appropriates nature at any given time, and this appropriation happens through the working process, based on certain development of productive forces and social relations of production"(6).

Therefore, the health-disease process simultaneously present social and biological features, and can be analyzed both by social and biological methodology, i.e., as a single process. The empirical study of health/disease process enables the description of a health status related to their social conditions, thereby evidencing the problem of health conditions in a more comprehensive than mere biological perspective, which directly influences the health practice ${ }^{(6)}$.

A relationship between the collective and the individual health/disease process is established, since the collective process determines the basic features on which the individual biological variation rests. Considering another point of view, it takes into account the social history of the individual, i.e., the set of relations and present conditions in someone's life, which will determine his/her biology and the likelihood of becoming ill in a particular way, resulting in the presence or absence of the phenomenon. The study of the health/disease process emphasizes the collective understanding of the causality issue, since the biological way of living in society determines the characteristic of biological disorders, and the disease itself, which appears not separate to this, but occurs as moments of a single but differentiable process $^{(6)}$. 
The social determination of health is a theoretical framework that discusses the scope of the collective and the socialhistorical nature of the health/disease phenomena, not focusing the debate on individual epidemiological data. It shows explicitly the relationship between biological and social features, diverging from the SDH approach, as seen below.

\section{SOCIAL DETERMINANTS OF HEALTH}

Until the nineteenth century, the representation of the disease was limited to two views based on single causality: the ontological and the dynamic. The ontological definition that prevailed in ancient times was defined by the attribution of the disease to an entity status, which was always external to the human being and with an existence on its own, an evil, i.e., such an entity was added to the patient's body, which that became a receptacle of a natural element or supernatural spirit that produces the disease by invading it. There was no participation or control of the body in the causation process ${ }^{(1)}$.

The dynamic view has its origin in the ancient Hindu and Chinese medicines on a dynamic conception of causality. It was thought that the disease was an imbalance or a disharmony between the principles or basic forces of life. However, it also contained the seek for this balance, i.e., the human being could seek different therapeutic procedures aiming at the restoration of his vital forces. Therefore, this view considers the disease's naturalization ${ }^{(1)}$.

In the $17^{\text {th }}$ and $19^{\text {th }}$ centuries, under the influence of the Cartesian paradigm, medical science developed rapidly, mainly with the progress of the Vesalius' Human Anatomy, which led to the emergence of another discipline, Physiology, which seeks to explain the normal functioning of the human body. Another subject that came up that time was Pathology, which allowed for the creation of a classification system for diseases $^{(1)}$.

In the $19^{\text {th }}$ century, a sanitary revolution began, as a way to intervene systematically on the physical environment and make it safer. Thereby, the foundations of Epidemiology began, "(...) towards the observation and documentation of diseases in populations when the infection paradigm overcame the atmospheric-miasma theory, after a clash that lasted from the $16^{\text {th }}$ until the $19^{\text {th }}$ century"(1).

The origin of diseases was explained by the prevailing socio-environmental paradigm, in which misery and miasma were used to explain the spread of disease. Chadwick's studies on the social causes for the absolute decrease of the English population and evidences from John Snow's research on the transmissible nature of cholera established the methodological bases of Epidemiology. The first evidence of the social determination of the health/disease process and the first models of government interference in public health started up with the English public health and the French social medicine. Such models were linked to ideological sanitation and social medicine movements existent at the time in England and Western Europe. Social medicine was born in France, founded on empirical observation of the relationship of disease and social conditions, and through this, the object of medicine began to move from disease to health ${ }^{(1)}$.
During the post-war period, the WHO concept for health in the late 1970s referred to the need to integrate medical care with fighting of the causes of disease. This concern also mobilized PAHO (Pan American Health Organization) and culminated in policies and intervention projects in countries with different historical backgrounds, such as Chile and Sweden. For some authors, the reappearance of Social Determinants of Health $(\mathrm{SDH})$ is related to the negative effects of the neoliberal model for development implemented in the 1980s. Such model increased health inequities, leading to the resurgence of concern for social justice $^{(12)}$.

In this sense, the level of health obtained by individuals would be due to social stratification, which determines the context or territory, as well as the uneven distribution of health-producing factors: of material, biological, psychosocial and behavioral nature. Economic inequality, characterized by the position that one occupies in the social stratification, determines unequal access to factors related to good or poor health, implying in an increase of local iniquities. Addressing inequality would mean the improvement of the health level, but to reach this, the development of intersectoral policies is needed (economic, employment, income, housing, education, etc.), ensuring people's participation and empowerment, so that they can collaborate with the transformation of society. Therefore, this emphasis on the revalue of individuals as subjects of their actions suggests that they are involved in the abovementioned structures and these, in turn, are involved in the meanings of social actions $^{(12)}$.

Currently, there is a consensus on the importance of $\mathrm{SDH}$ in health status, which was built throughout history. These were highlighted in the late 1970s in the Alma-Ata Conference, and in the 1990s, with the debate on the Millennium Development Goals, which was ratified with the creation of the World Health Organization Commission on Social Determinants of Health in $2005^{(13)}$.

In 2006, a Presidential Decree creates the National Commission on Social Determinants of Health (NCSDH) in Brazil. This committee sets SDH as social, economic, cultural, ethnic/racial, psychological and behavioral factors that influence the occurrence of health problems and their risk factors in the population ${ }^{(13)}$.

In general, it is considered that the $\mathrm{SDH}$ represent the relationship between the living and working conditions of individuals with their health status. The World Heaçth Organization adopts a more succinct definition of the SDH as the social conditions in which people live and $\operatorname{work}^{(13)}$.

The activities of NCSDH are based on the WHO concept of health: "a state of complete physical, mental and social well-being and not merely the absence of disease or infirmity"; and the constitutional principle that recognized health as a "(...) right and duty of the state, ensured through social and economic policies aimed at reducing the risk of disease and other health problems, as well as policies for the universal and equal access to actions and services for health promotion, protection and recovery"(13-14). 
The main NCSDH objectives are: to produce knowledge and information on SDH in Brazil; to contribute to the development of policies, plans, models and programs to promote health equity; and to mobilize the civil society and the government to address $\mathrm{SDH}^{(15)}$.

There are several models that investigate $\mathrm{SDH}$ and describe the relationships between several general factors such as the social, economic and political ones. The reference model adopted by NCSDH is the Dahlgren and Whitehead model set in $1991^{(13,16)}$. This model places SDH in different layers: from a layer that is closer to the individual determinants until a layer where the macro determinants are. This model identifies four levels of possibilities to address these determinants, interrelated and not mutually exclusive ${ }^{(13)}$.

The first level is related to individual factors, behavior and lifestyle, and strongly influenced by the SDH, since it is difficult to change risky behavior without changing the cultural norms that influence them. The addressing strategies consist of population coverage of policies that promote behavior change in relation to risk factors or actions to strengthen the ability of people to cope better with the negative influences arising from their living and working conditions. Some examples would be to educate people working in monotonous conditions to deal with stress or advise people who are unemployed to prevent the decline of mental health associated with this condition ${ }^{(13)}$.

The second level is related to the social networks and communities. The social bonds and relations of solidarity and trust between people and groups are essential for the promotion and protection of individual and collective health, that is, this level focus is the strengthening of communities organization and participation in collective actions, so that individuals recognize themselves as social actors and active participants of social life decisions ${ }^{(13)}$.

The third level refers to factors related to the living and working conditions. At this level people in social disadvantage are subject to risks arising from poor housing conditions, exposure to hazardous and stressful working conditions, and less access to essential services. Proposals to address these problems are policies to ensure better access to clean water, sewage system, adequate housing, healthy food, essential health services, education, healthy work environments and a secure and satisfactory job, among others ${ }^{(14,16,17)}$.

The fourth and final level includes economic, cultural and environmental conditions prevalent in society as a whole. The actions on this level is based on macroeconomic and labor policies, strengthening of cultural values and environmental protection, aimed at the promotion of sustainable development, reduction of socioeconomic inequalities, violence, environmental degradation and its effects on society ${ }^{(13,16)}$.

\section{COMPARATIVE ASPECTS BETWEEN SDH AND SOCIAL DETERMINATION OF HEALTH}

Since 2005, WHO publishes about the theme social determinants of health, which starts to be studied by several countries affiliated to this multilateral cooperation institution. But the concept of social determinants reappears devoid of the previous 1970s and 1980s theoretical and political framework, in which the comprehension was related to the Marxist theory of society, based on the critical issue of the social thought ${ }^{(7)}$.

In this critique, it is assumed that, most times, cases are presented under the SDH when the social causality of health problems is almost obvious, such as statistics that show high mortality rates in children from low-income families when compared to other strata of the population. Another example is the comparison of episodes of depression and other mental disorders among unemployed and employed people, because the first are more susceptible to this kind of conditions ${ }^{(7)}$.

It appears that the current approaches to social determinants are limited to identifying correlations between social variables and morbidity/mortality events in the population, unlike what was intended in the 1970s and 1980s, when a broader explanatory perspective was sought. Deepening the analysis, it is assumed that interests related to the hegemony of knowledge fields can also be present; however, they are not immediately recognized: "Therefore, what is revealed behind the label of social determinants and behind the fight against health inequities is the overwhelming triumph of the traditional epidemiology perspective"(7).

Some institutions of the public health field today also weave such criticisms, such as the Brazilian Center for Health Studies (known by its Portuguese acronym CEBES) and the Latin American Association of Social Medicine (ALAMES). These organizations understand that the apparent new studies on social determinants field emphasize the predominant positivist perspective of traditional epidemiology $\mathrm{y}^{(7)}$.

According to the WHO model, the social determinants are considered factors externally connected, expanding the vision of the so-called causes of the causes. It is indeed worrying, since this model repeated the modus operandi of causalism, i.e., to act on factors. Even though this model recognizes the structural and intermediate determinants, it does so in such a way that it is impossible to establish the historical link between the dimensions of life $\mathrm{f}^{(18)}$.

A first limiting factor of this perspective is the absence of defining categories of the studied set and its logic (accumulation, property, social relations) and structural determinants, in addition to the emphasis on policy and governance. Another point is the linear version of the components of social classes (education, work/occupation) and its tendency to value the economic dimension in the definition of social strata, as seen in the analyzes of the emergence of a new middle class in Brazil, based only on consumption indicators. As for the intermediate determinants, it remains unclear what the material circumstances are involved, and whether they correspond to social or to the individual production level ${ }^{(18)}$.

In turn, the Marxist-based concept imposes another episteme, and proposes an understanding in which the objective measurements of an observable phenomena (and 
then including the concept of risk factor, for example) should be considered in the dynamic mediations between levels in which the social processes occur, rather than bringing the variables for a given level of analysis. The criticism that addresses the aspects of the positivist theories is that while "using methods of the natural sciences in the social world, they enable a fragmented understanding of the study problem and photographs the reality in a static manner, covering up the consciousness of the dynamics which highlights the picture that determinate of what is being studied"(19).

The neopositivism and the contemporary science reduced the concept of social health determinants to an empirical causal factor through statistical methods and inferences $^{(7)}$. Some authors state the importance of reviewing the social determinants of health in order to overcome the positivist notion expressed in the SDH concept, because the theory on the social production of health encompasses the social-historical character of the health/disease phenomena, enabling the clarification of the relationships between biological and social features, and between individual and collective issues $^{(18)}$.

Thus, we think that the use of the term Social Determination is opposed to the $\mathrm{SDH}$, and that the first one brings a basic question not only about the theoretical and methodological bases concerning studies that support the SDH concept, but also epistemological questioning on the basis that science should be built, while seeking to understand the issues of life and illness beyond the phenomena through which they are expressed ${ }^{(18)}$. Briefly, it can be said that Social Determination is understood as a perspective that considers the broader field in which health/disease process is produced, aiming to bring consciousness of the established mediations between the fragmented reality and the social totality, whereas the SDH expresses a preference for identifying measurable social variables on a more descriptive but dense understanding of the health contexts ${ }^{(4,7,18)}$.

Based on the Theory on the Social Production of Health, it is assumed that this is an eminently human and social phenomenon, not a biological-natural fact, which requires a complex approach that should be historically, politically and culturally contextualized. This is not, however, the predominant approach, since most of the studies are focused on identifying correlations between isolated social variables and mortality events in the population without advance further analysis. The criticism lies in the assumption that the health determination is beyond the simple application of causal schemes, and not merely an empirical comparison between health and social factors ${ }^{(7)}$.

The individual biological process does not immediately reveal the social process. A look beyond is needed to guide the object of clinical medicine and epidemiology and build a study object that allows for an empirical investigation of the problem, since "(...) empirically, the social character of the health/disease process is clearer at the community level than at the individual level"(6).

Therefore, Social Production of Health as a theoretical discussion framework includes the community and the social-historical character of the health/disease, not just the discussion of individual epidemiological data, which provides the clarification on the relationship between the biological and the social, constituting the social determination of health.

\section{FINAL CONSIDERATIONS}

Internationally, the SDH have been considered as a prominent issue, discussed in the Brazilian society mainly by the NCSDH. Such is the importance of this issue that many countries are supporting their policies through the study and analysis of SDH. However, the present analysis on the nature of concepts revealed a tendency to approach health data in a positivist and reductionist way, especially when discussing epidemiological data individually, without considering all the social factors that may or may not be involved in the process of illness among individuals and populations.

It is noteworthy that health is more than a biologicalnatural fact and more than the application of epidemiological schemes. It is part of the living of an individual in a society, and it is related to the access to socio-economic networks and essential services. This is to say that the social context and the history of individual life and collective living will influence positively or negatively on health, which is eminently a human phenomenon.

The implications of the adoption of these perspectives as a theoretical framework to the field of public health assume different natures. First, one must clearly recognize that the education of future health professionals demands the inclusion of theoretical perspectives that supports the pedagogical project in their curriculum guidelines, resulting in a whole set of choices on several issues, such as the relationship between theory and practice in teaching, the privileging of certain disciplinary matrices over others, just to name a few.

Also within the definition of public policies - here understood as an expression of dispute arenas for politi$\mathrm{cal}$ and ideological interests in addition to their technicalscientific basis - the adoption of one or another perspective can support (or not) a more or less focused action, depending on how one will structure these political processes of implementation.

It is noted from the readings that in the set of political agendas oriented to the financing and implementation of actions focused on the health/disease processes, there is an hegemony of a technical view based on targeted actions that replace each other, or even contradict or overlap each other, without considering the specific historical and social dimension.

Therefore, by bringing these points to debate, albeit briefly, it is clear that the discussion needs to be broadened beyond the academic realm, including health professionals, managers, professors and students of health professions courses, so that the clarifications of the origin and the guiding principles of the concepts will allow for informed choices and the appropriation of theoretical and conceptual discussion by all those involved in the production of health. 


\section{RESUMO}

Este artigo tem como objetivo discutir os conceitos de Determinação Social da Saúde e de Determinantes Sociais da Saúde, tecendo uma comparação entre suas perspectivas orientadoras e as implicações para as políticas e ações de saúde. Desenvolve-se uma reflexão de caráter histórico e conceitual, destacando a Teoria da Produção Social da Saúde, seguindo-se uma discussão sobre os conceitos, com abordagem comparativa entre estes.

\section{DESCRITORES}

Determinantes Sociais da Saúde; Epidemiologia; Medicina Social; Enfermagem em Saúde Pública.

\section{RESUMEN}

Este artículo tiene el fin de discutir los conceptos de Determinación Social de la Salud y de Determinantes Sociales de la Salud tejiéndose una comparación entre sus perspectivas orientadoras y las implicaciones para las políticas y acciones de salud. Se desarrolló una reflexión de carácter histórico y conceptual, destacándose la Teoría de la Producción Social de la Salud, siguiéndose una discusión acerca de los conceptos, con abordaje comparativo entre esos.

\section{DESCRIPTORES}

Determinantes Sociales de la Salud; Epidemiología; Medicina Social; Enfermería en Salud Pública.

\section{REFERENCES}

1. Oliveira MAC, Egry EY. A historicidade das teorias interpretativas do processo saúde-doença. Rev Esc Enferm USP. 2000;34(1):9-15.

2. Medeiros ARP de, Larocca LM, Chaves MMN, Meier MJ, Wall ML. Epidemiology as a theoretical-methodological framework in the nurses' working process. Rev Esc Enferm USP. 2012;46(6):1519-23.

3. Amador DV, Silva KL. Promoção da Saúde: histórico, conceito e práticas no contexto da saúde coletiva. In: Souza MCMR, organizadores. Enfermagem em saúde coletiva: teoria e prática. Rio de Janeiro: Guanabara Koogan; 2013. p. 15-24.

4. Fleury-Teixeira P. Uma introdução conceitual à determinação social da saúde. Saúde Debate. 2009;33(83):380-7.

5. Lupton D. Risk. London: Routledge; 1999.

6. Laurell AC. A saúde-doença como processo social. Rev Latino Am Salud [Internet]. 1982 [citado 2014 maio 20];2:7-25. Disponível em: http://xa.yimg.com/kq/groups/23089490/574657748/name/saudedoenca.pdf

7. Nogueira RP, organizador. Determinação social da saúde e reforma sanitária. Rio de Janeiro: CEBES; 2010.

8. Foucault M. Microfísica do poder. Rio de Janeiro: Graal; 1979.

9. Nunes ED. Saúde coletiva: uma história recente de um passado remoto. In: Campos GWS, Minayo MCS, Akerman M, Drumond Junior M, Carvalho YM, organizadores. Tratado de saúde coletiva. São Paulo; 2009. p. 19-40.

10. Viana NS, Soares CB, Campos CMS. Reprodução social e processo saúde-doença: para compreender o objeto da saúde coletiva. In: Soares CB, Campos CMS, organizadores. Fundamentos de saúde coletiva e o cuidado de enfermagem. Barueri: Manole; 2013. p. 107-42.

11. Campos GWS. Clínica e saúde coletiva compartilhadas: teoria Paidéia e reformulação ampliada do trabalho em saúde. In: Campos GWS, Minayo MCS, Akerman M, Drumond Junior M, Carvalho YM, organizadores. Tratado de saúde coletiva. São Paulo: Hucitec; 2009. p. 41-80.

12. Zioni F, Westphal MF. O enfoque dos determinantes sociais de saúde sob o ponto de vista da teoria social. Saúde Soc. 2007;16(3):26-34.

13. Buss PM, Pellegrini Filho A. A saúde e seus determinantes sociais. Physis Rev Saúde Coletiva. 2007;17(1):77-93.

14. Brasil. Constituição, 1988. Constituição da República Federativa do Brasil. Brasília: Senado; 1988.

15. Brasil. Decreto Presidencial, de 13 de março de 2006. Institui, no âmbito do Ministério da Saúde, a Comissão sobre Determinantes Sociais da Saúde - CNDSS [Internet]. Brasília; 2006 [citado 2014 abr. 20]. Disponível em: http://www.planalto.gov.br/ccivil_03/_Ato20042006/2006/Dnn/Dnn10788.htm

16. Comissão Nacional sobre Determinantes Sociais da Saúde (CNDSS). As causas sociais das iniquidades em saúde no Brasil [Internet]. Rio de Janeiro; 2008 [citado 2014 abr. 20]. Disponível em: http://www.determinantes.fiocruz.br/

17. Comissão de Determinantes Sociais de Saúde. Rumo a um modelo conceitual para análise e ação sobre os Determinantes Sociais de Saúde: ensaio para apreciação da Comissão de Determinantes Sociais de Saúde [Internet]. Rio de Janeiro: CSDH; 2005 [citado 2014 abr. 20 ]. Disponível em: http://www.determinantes.fiocruz.br/pdf/texto/T4-2_CSDH_Conceptual\%20Framework\%20-\%20tradu\%E7\%E3o\%20APF.pdf

18. Breilh J. Las tres "s" de la determinación de la vida y el triángulo de la política. In: Nogueira RP, organizador. Determinação social da saúde e Reforma Sanitária. Rio de Janeiro: CEBES; 2010. p. 87-125.

19. Soares CB, Campos CMS, Yonekura T. Marxism as a theoretical and methodological framework in collective health: implications for systematic review and synthesis of evidence. Rev Esc Enferm USP. 2013;47(6):1403-9. 